in plasma globulin, the changes reaching a maximum about twelve hours after.

If an animal was first immunized to an antigen (sheep's red cells) and then some months later, when all the antibody had disappeared from the blood, injected with adrenal cortex hormone, the antibody reappeared in the blood in considerable amount. The therapeutic implications of this experiment are obvious and will no doubt be explored. It has also been shown that the total amount of lymphoid tissue present in the body is determined and controlled by the adrenal cortex, and the normal age involution of the lymphoid tissue (including the thymus) is ascribed to an increasing activity of the adrenal cortex, which is in turn due to an increasing activity of the anterior pituitary. The pituitaryadrenal mechanism for the release of $\gamma$-globulin and antibodies can be activated experimentally in a number of ways, for example, by hæmorrhage, heat, cold, X-rays, foreign proteins, injection of benzene or arsenite. From another point of view the lymphocytes of the body represent a considerable store of protein which can be rapidly released by the pituitaryadrenal mechanism in states of emergency.

Reports of a repetition of this work have not yet been published, and confirmation or otherwise of the somewhat surprising results will be awaitod with interest.

O. A. TrowerLL

\section{MINERAL PRODUCTION OF CANADA}

“T HE Canadian Mineral Industry in 1945", published by the Bureau of Mines, Ottawa (1946, pp. 103), contains reviews of the various metals, industrial minerals and fuels produced in the Dominion during 1945, and gives particulars in each case of sources of supply, uses, prices and tariffs, and figures for production, exports and imports. In order of value (stated in millions of dollars) the chief products are: aluminium $(133 \cdot 6)$; gold (103.8); coal $(67 \cdot 6)$; nickel $(62)$; copper $(59 \cdot 3)$; zine $(33 \cdot 3)$; platinum group $(26 \cdot 7)$; asbestos $(22 \cdot 8)$; lead $(17 \cdot 3)$; cement $(14 \cdot 2)$; petroleum $(13 \cdot 6)$; lime, limestone and marble $(13 \cdot 2)$; natural gas $(12 \cdot 3)$; sand and gravel $(10 \cdot 6)$; clay and clay products $(8.3)$; silver (6); salt (4); peat (2); pyrite and sulphur $(1.9)$; gypsum $(1 \cdot 8)$; silica $(1.5)$; barite $(1 \cdot 3)$; magnesitic dolomite and brucite $(1 \cdot 3)$; granite $(1 \cdot 1)$; sodium sulphate $(0 \cdot 9)$; selenium $(0 \cdot 7)$ and cadmium $(0 \cdot 6)$. No corresponding figure for iron ore is given, but it is interesting to note that production, negligible only a few years ago, has recently increased onormously, and is expected soon to equal the requirements of the Canadian iron and steel plants. The Helen Mine, north of Lake Superior, and the Steep Rock Mine, west of Port Arthur, each produced more than half a million tons during 1945 and have very substantial reserves.

The temporary disappearance of magnesium from the above list is a symptom of war-time overproduction, large stocks of the metal and its alloys having already been accumulated in Ontario. It may be a surprise to many to find aluminium at the head of the list. Although there is no bauxite in Canada, the Canadian aluminium industry is the second largest in the world, being exceeded only by that of the United States. The favouring factors are the low costs of hydro-electric power at points where the necessary raw materials can be cheaply assembled.

Canada's dominating position as a source of nickel is well known; it remains at about 80 per cent of the world total. Despite the drastic reduction in munitions manufactures, the many new uses found for nickel during the War, as in radar and extended utilization of nickel-bearing steels, are expected to provide an expanding market. Canada continued to be one of the leading exporters of copper, and to maintain its position-gained from the U.S.S.R. in 1934-as the leading producer of the platinum and palladium group of metals. Coal production is down a little and petroleum by as much as 15 per cent.

Production of oil from the Turner Valley field has been decreasing since 1942. The search for new fields in Alberta has so far been disappointing, but six producing wells have been completed in Saskatchewan, which appears as a small producer for the first time. The development of natural gas resources has been more successful, especially in Alberta. The new gas field recently discovered in Ontario beneath the floor of Lake Erie was brought into production by means of wells put down a mile from the shore.

\section{ANALYTICAL GEOLOGY}

'HIS is the name given by A. B. Vistelius to the application of statistical analytical methods to numerical geological data and the subsequent interpretation of the results in the light of significant geological facts. In a series of five short articles*, he applies this method to the study of the porosity of rocks belonging to the oil-bearing strata of Permian age in the Transvolgian region of the U.S.S.R. The original data consist of a number of records of the coefficients of porosity $(y)$ of rocks, taken in a number of bore-holes at a certain depth $(x)$ below a definite stratigraphical horizon. Plotting the coefficient of porosity against depth, Vistelius obtains broken-line diagrams which are smoothed out so as to give continuous curves. It is then discovered that for all the bore-holes of the region these curves correspond to a definite formula, the equation of which is originally given as

$$
\begin{array}{r}
y=m+n x+\exp \left(a_{1} x+b_{1}\right) \cos \left(\omega_{1} x-\varphi_{1}\right)+ \\
\exp \left(a_{2} x+b_{2}\right) \cos \left(\omega_{2} x-\varphi_{2}\right),
\end{array}
$$

and then reduced to a general serial expression of the type

$$
\begin{gathered}
y=\sum_{i=0}^{k} \exp \left(a_{i} x+b_{i}\right) \cos \left(\omega_{i} x+\varphi_{i}\right) \\
\text { where } k \leqslant 3 .
\end{gathered}
$$

Then the coefficients $a_{i}, b_{i}, \omega_{i}$ and $\varphi_{i}$ are calculated for each bore-hole and the analogous coefficients for different bore-holes are compared and plotted on the geographical map by means of isopleths (contour lines corresponding to equal numerical values).

The isopleth maps, showing the regional distribution of the numerical values of the coefficients of the generalized formula, are then compared to other maps such as strato-isohyps maps or isopachyte (lines of equal thickness of a bed) maps of the region, and it is discovered that the isopleth maps of certain coefficients are analogous either to structural isohyps maps or isopachyte maps. This suggests that the distribution of porosity in a sedimentary complex

- Vistelius, A. B., Compt. Rend. (Doklady) Acad. Sci. URSS., 44, No. 1,27 (1944); 49, No. $1,44(1945) ; 49$, No. $7,531(1945)$
54, No. 6, $519(1946) ; 55$, No. 3, 241 (1947)'(Rusian text). 
obeys not only a certain periodic law, as expressed by the general formula, but is also linked up with the general geological structure of the region and is therefore related to the geological history of the sedimentary complex. The coefficient of periodicity ( $\omega)$ appears to be especially significant, and the isopleth maps of this coefficient can be easily correlated with either the structural maps or the isopachyte maps. According to whether the members of the equation contain the minimum, maximum or intermediate value of $\omega$, they are called micro-, macroor meso-rhythms.

To Vistelius all this suggests that porosity is closely related to the processes of deposition and epigenesis (cementation and leaching), and so can be used as a measure of what he calls the "phase differentiation' of the sedimentary complex, the phases in this case being the solid phase (mineral components of rocks) and the liquid and gaseous phases (infilling the pore space). If the empirical equation of the vertical distribution of porosity is compared with the equation expressing the normal law of errors, or rather the function of distributed probabilities, one is able to get an estimate of the magnitude of the secondary processes (epigenesis) as compared with the magnitude of the primary processes (sedimentation). This is achieved by the construction of isopleth maps for kurtosis and skewness, which provide a sensitive method of discovering the distribution of 'fossilized processes'.

All this work is still in its pioneering stage and as presented can be appreciated only by geologists well versed in modern statistical methods. It is rather difficult to evaluate the significance of isopleth maps for equation coefficients when these are compared with structural contour maps (isohyps or isopachytes). In spite of this difficulty, this work appears very interesting and important. There is a suggestion that this method may have a wider applicability to geological problems in which the immediate data do not allow any direct correlation or deduction. The practical importance of the application of statistical methods to geology may be considerable. In the case discussed by Vistelius, the porosity of the rocks has a direct bearing on the distribution of reservoir beds in an oilfield, but it is not difficult to find many other instances of work of economic value in which statistical methods may have an application. Such are, for example, water supplies, distribution and grade of coal in coalfields, and other similar problems.

S. I. TOMKEIEFF

\section{ELEMENTARY PARTICLES AND THE GEOMAGNETIC FIELD}

$\mathrm{R}$ ECENTLY J. Barnóthy ${ }^{1}$ has proposed an explanation of the elementary particles (protons, electrons, etc.) in terms of serial universes, each enclosed in one of higher order. The elementary particles of our universe are universes of a lower order; our universe is an elementary particle in a higher universe. The universes are three-dimensional curved ones enclosed in a four-dimensional space; that of an elementary particle has a two-dimensional intersection with our universe, which delimits a region excluded from the latter. Mass in an elementary universe becomes imaginary mass $(\sqrt{-1} \times$ mass) when viewed from ours; the gravitational attraction between two imaginary masses is a real electrostatic force. The spin of an elementary universe gives parts of its mass a velocity greater than $c$; this makes the imaginary mass acquire real linear and angular momentum. Nuclear forces in our universe are the counterparts of cosmical repulsions in the elementary universe. Protons and electrons arise from Einstein universes of negative and positive curvature ; a neutron is formed by the combination of a proton and another particle arising from a de Sitter universe.

Barnóthy expresses these general ideas in a quantitative form. Like Eddington, by some of whose ideas he has been profoundly influenced, he derives an impressive list of theoretical values of fundamental constants, in good agreement with the experimental values. One must add that, again as with Eddington, it is often difficult to trace the interconnexions between different parts of his argument. In particular, the mechanism by which internal properties of a micro-universe react on our universe is far from clear.

Barnothy claims to explain the proportionality between magnetic moment and angular momentum of sun and earth, to which Blackett and Babcock have recently directed attention. [Barnóthy's work was not suggested by that of Blackett and Babcock; a preliminary account of his ideas, dated September 13, 1946, was received by Nature last year, but was not regarded as sufficiently explicit to warrant publication. EDIToRs.] He asserts that protons and neutrons possess, besides their real mass, an imaginary mass 643 times the electron-mass, and this imaginary mass behaves like an electric charge. The rotation of such a charge would produce terrestrial and solar magnetic fields of just the observed order of magnitude; but the suggestion is not at present satisfactory, since such a charge would produce a formidable electrostatic field, and Barnóthy declines to consider this field for the present.

T. G. Cowling

${ }^{1}$ Hungarian Institute for Meteor. and Terr. Mag., Papers on Terrestrial Magnetism, No. 2 (1947).

\section{FORTHCOMING EVENTS}

\author{
(Meetings marked with an asterisk * are open to the public)
}

\section{Monday, December 15}

Royal Physioal Soctety of EdInBdrgh (at the Royal Scottish Geographical Society, Synod Hall, Castle Terrace, Edinburgh), at 5.15 p.m.- Symposium on "The Species Concept".

MANChESTER IITERARY AND PHILOSOPHICAL SOCLETY (in the Reynolds Hall, College of Technology, Manchester), at 5.30 p.m. Prof. T. B. L. Webster: "Three Interpretations of Greek Vases" (Presidential Address).*

INSTITUTION OF THE RUBBER INDUSTRY, MANCHESTER AND DISTRICT SECTION (joint meeting with the SOCLETY OF CHEMICAL INDUSTRY, at the Engineers' "Club, Albert Square, Manchester), at 6.15 p.m.-Dr. ROYAL INSTITUTE OF CHEMISTRY, LONDON AND SOUTH-EASTERN CounTIEs SkCTION (at Norwood Technical Institute, Knight's Hill, London, S.E.27), at 7 p.m.-Microchemical Exhibition and Demonstration (organised by Mr. J. T. Stock).

\section{Tuesday, December 16}

ROYAL SOCIETY OF ARTS, DOMINIONS AND COLONIRS SECTION (at John Adam Street, Adelphi, London, W.C.2), at 2.30 p.m.-Mr. Colin Colahan: "Australian Art".

ROYAL ANTrRopologidar INSTITUTE (at 21 Bedford Square, London, W.C.1), at 5 p.m.-Dr. F. Hepner : "Communications and History". EdGenios Socretr (at the Royal Society, Burlington House, Piccadilly, London, W.1), at 5.30 p.m.-Dr. J. A. Fraser Roberts and Dr. Eliot Slater: "Genetics, Medicine and Practical Eugenics"."

Instrtution of Crvil EnginesRs (at Great George Street, London, S.W.1) at 5.30 p.m. - Sir Charles Inglis, F.R.S.: "Mathematics in S.W.1) at special Reference to a Recent Paper by the Lecturer on Shear Stress Determination".

SOCIRTY OF CHEMTCAL INDUSTRY, CHEMIOAL ENGINERRING GROUP (at the Geological Society, Burlington House, Piccadilly, London, W.1), at 5.30 p.m.-Mr. J.' G. Window: "Glass Equipment in the Chemical Engineering Industries". 